\title{
Esophageal Squamous Cell Carcinoma
}

National Cancer Institute

\section{Source}

National Cancer Institute. Esophageal Squamous Cell Carcinoma. NCI Thesaurus. Code C4024.

A squamous cell carcinoma arising from the esophagus. It is associated with a long history of tobacco and alcohol abuse and is exceedingly rare before the age of 30 . The median age is around 65 in both males and females. It is located mostly in the middle and lower third of the esophagus. Grossly, polypoid, ulcerated, plaque-like and occult lesions have been described. The microscopic features are the same as in other squamous cell carcinomas. Any degree of differentiation may occur, and variation within a single tumor is common. The prognosis is poor. 